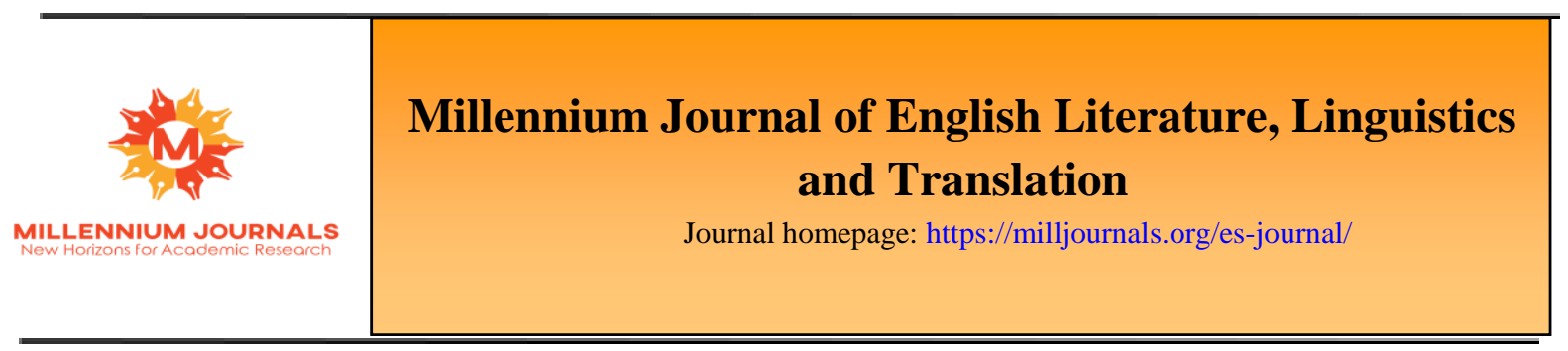

\title{
An Exploration of Yemeni University Students' Attitudes Towards Learning Linguistic Courses Using Google Classroom
}

\author{
Mohammad Abdu Ahmad Al-Mekhlafi \\ Department of English, College of Education, Sana'a University, Yemen \\ https://doi.org/10.47340/mjellt.v1i1.1.2020
}

\begin{abstract}
This research paper intends to investigate the attitudes of Yemeni university students towards using Google Classroom as a learning tool. It also aims to explore any similarities and differences between graduate and undergraduate students and between males and females in terms of their attitudes towards using Google Classroom as a learning tool. This study employed a quantitative approach. One hundred and twenty students of the fourth level of the B.Ed. program and forty students enrolled in the M.Ed. program at the Department of English in the College of Education at Sana'a University in Yemen participated in this study during the academic year 2018/2019. Data were collected using a questionnaire whose analysis revealed a positive attitude towards using Google Classroom as a learning tool. The findings of this study indicated that the highest mean average among the five components of the attitude scale was the Behavioral Engagement (BE) $(\mathrm{M}=$ 4.09), followed by Developing Language Skills $(M=4.04)$ and the Linguistics Confidence ( $M=$ 3.92). Finally came the Attitude to Learning Linguistics with Technology $(M=3.76)$ and the Technology Confidence $(M=3.56)$. This study concluded that there was a statistically significant difference between the mean of the undergraduate and graduate students towards using Google Classroom as a learning tool in favor of the graduate students. Furthermore, there was no statistically significant difference between male and female students in terms of their attitudes towards using Google Classroom. This study ends with some pedagogical implications and directions for future research studies.
\end{abstract}

Keywords: Google classroom, students' attitudes, gender, linguistics courses

\section{Introduction}

Mobile phones and laptops are valuable educational resources for students and teachers whose educational institutions do not have access to the Internet. The Yemeni schools and universities are a case in point. The students can use their mobile phones and connect to the Internet from remote locations at any given time. What is more, having an online learning environment such 
as Google Classroom encourages knowledge sharing and collaboration between the students. It also influences the students to study on their own and become self-dependent. Furthermore, it provides the opportunity for the teacher to give the needed guidance to their students. Google Classroom can be defined as "a free web service that allows teachers and students to create, share and manage online courses with real-time discussions and task management" ("Google Classroom," 2019). It was launched publicly on August $12^{\text {th }}, 2014$.

Integrating technology into the classroom can make learning and teaching more effective, fun and enjoyable. Teachers can use various online resources to enhance the traditional ways of teaching and to keep their students more engaged. When teachers integrate technology into their classes, their students become more interested in the subjects they are studying.

Technology devices like computers and mobile phones play a major role in the field of education. They also play a role in instilling in the learners a love of language learning. With the help of technology devices, the learners take language learning as a fun game. Furthermore, technology-based instruction produces significant changes in the attitude of the students (Tomar, 2016). Thus, in the modern world, there is a need for students at different schools and universities to be more receptive and use their technology devices in the learning process. Teachers can encourage their students to use Google Classroom in doing their own class work assignments. They can benefit from the students' high use of their own mobile phones and computers outside the classroom. Almekhlafi (2006) reported that the perceived benefits of using computers and mobile phones in language learning contribute to the students' positive attitude towards technology and their willingness to keep using it to practice the English language in other contexts in the future.

\section{Literature Review}

With the advancement of technology, mobile phones have now replaced the classic telephones used at homes. The integration of mobile phones and computers in foreign/second language classes has been investigated in a number of studies. The use of technology has been shown to have an impact on foreign and second language learning (Almekhlafi, 2006; Ambu-Saidi, 2010; Awad and Alkaraki, 2013; Kitchakarn, 2015 among others). Online feedback that the students receive from their teachers, whether explicitly or implicitly, is a good motivation for the learners to improve their language skills and learn from their mistakes (Ambu-Saidi, 2010).

Computers and mobile phones have the ability to present authentic texts in innovative ways. They also allow students to share their own assignments and learn from each other. This leads to enhanced motivation and the establishment of an identity in the learning of a second language (Nicholas, Rossiter, and Abbot, 2011; Behroozian and Sadeghoghli, 2017). They also help students to have access to different learning sources not only inside the classroom, but also outside of it. They also make the learning process more student-centered (Behroozian andSadeghoghli, 2017).

The use of technology in the classroom is helpful in facilitating teaching and learning for both teachers and students (Yang, 2017). Some research studies have demonstrated that the proper use of technology in the classroom can raise the educational quality in the higher educational institutions (Sánchez \&Alemán, 2011; Yang, 2017). Technology has become "an integral part of education as it offers innovations and interaction for both students and teachers" (Karakaya, 2010, p. 15). 
However, integrating technology effectively into the classroom is much more complicated than providing computers and securing a connection to the Internet (Tondeur, Cooper \& Newhouse, 2010; Sreedhar \& Amos, 2016). Some researchers have reported that technology use is timeconsuming (Ambu-Saidi, 2010).

\subsection{Google Classroom}

Google Classroom is a free e-learning platform for teachers to create and teach online courses. Google Classroom enables teachers to create their online courses with text, pictures, videos, multimedia and file attachment. It also allows teachers to create their own quizzes and tasks. The tasks are graded by the teacher online and every student is shown his own grade while the quizzes are graded automatically which saves the teacher's time and efforts. Google Classroom is similar to Moodle and other learning management systems, but free of charge. It plays a role in democratizing education with technology and it was unveiled to public in August 2014.

\subsection{Attitudes towards Using Technology}

Research studies regarding the attitudes of students and teachers towards the use of technology in the second/ foreign language learning are quite numerous. Some researchers believe that the successful integration of technology in school and university instruction depends mainly on the students' and teachers' attitudes (Venkatesh and Bala, 2008; Teo et al., 2015).

In the Omani context, Ambu-Saidi (2010) investigated the attitudes of both students and teachers towards the use of technology in a tertiary English course in an Omani College of Applied Sciences. She collected her quantitative and qualitative data by means of a questionnaire and interviews. Her findings indicated that the students embraced technology as a constructive learning tool.

In Turkey, Karakaya (2010) investigated the attitudes of 87 in-service schoolteachers towards computer technology and their use in teaching at schools. He reported that the majority of the English teachers attributed positive attitudes for integrating technology in language teaching.

In Spain, Sainz and Lopez-Saez (2010) investigated the attitudes of 550 secondary school students towards the use of computers in language learning. They collected their data by means of a survey questionnaire. Their results indicated that the female students got the lowest scores in all the dimensions of computer attitudes and their components.

In the Jordanian context, Awad and Alkaraki (2013) tried to explore the attitudes of 100 students in the secondary schools towards the use of technology. They found that computer-assisted English language lessons have a positive effect on the students' attitudes. They also found that older students have a positive orientation and consciousness of the benefits of using computers in language learning.

Abedalaziz, Jamaluddin and Leng (2013) conducted a study to explore the attitudes of 289 postgraduate students toward the Internet and computer use in the Malaysian context. They collected their data by means of an attitude questionnaire. Their results revealed that the student's attitudes toward computer and Internet usage is high and age related.

In Iran, Behroozian and Sadeghoghli (2017) explored the students' attitudes towards using computers and the Internet in English language classes. They collected their data from 5 students 
and 3 teachers by means of interviews. Their results showed that the students had positive attitudes towards the use of technology in the English classes. They also concluded that age was the most significant predictor of student attitudes towards technology.

A recent study was conducted in the Indian context by Islahi (2019) who explored the attitudes of 482 secondary school teachers. She collected her data by means of a questionnaire. Her results reported that her participants held somewhat a positive attitude towards technology use in teaching.

To sum up, the various research studies regarding the attitudes of students and teachers towards using computers and mobile phones as learning tools have yielded valuable information which would benefit the teachers, syllabus designers and policy makers to know the attitudes of the students.

\subsection{Previous Studies within the Framework of Gender Differences}

Throughout the existing body of literature, one can find that the previous studies which were conducted within the framework of gender differences reached different and contradictory conclusions. Some of them claim that gender can have an impact on the attitudes of students towards using technology in language learning. For example, Sainzand Lopez-Saez (2010) found that the males in the Spanish context were more motivated, and had a more positive attitude than their female counterparts. Similar results were reported by Colley and Comber (2003) who found that the male respondents showed more interest and more enjoyment than the female respondents in technology use. Colley andComber concluded that gender plays a significant role in forming the attitudes towards using technology. Moreover, Teo et al. (2015) examined the possible gender differences in the pre-service teachers' perceived acceptance of technology in their schools. They reported a statistically significant difference in the way male and female pre-service teachers perceived computers to be easy or difficult to use. The male pre-service teachers had higher scores on the perceived ease of use of computers in teaching.

On the other hand, a study by Awad and Alkaraki (2013) was conducted to explore whether the attitudes of male and female students were significantly different or the same. They conducted their study among 50 female and 50 male Jordanian students studying English at schools. The researchers collected their data by means of a questionnaire. Their results revealed that gender has no clear impact on students' attitudes towards using computers in learning English.

Another related study is Abedalaziz, Jamaluddin and Leng (2013) who carried out their study with 289 Malaysian postgraduate students. They reported that no significant differences were found between the male and female postgraduate students' attitudes toward the Internet and computer use.

Kitchakarn (2015) aimed at determining if there was a statistically significant difference between the male and female students' attitudes towards using computers in language learning. His subjects were 70 male and 122 female students studying two English courses in Bangkok University in Thailand. The findings of his study indicated no significant differences among males and females.

A recent study was carried out by Islahi (2019) who examined the attitudes of 482 Indian teachers towards the use of technology in teaching at schools. She concluded that although the male 
teachers recorded slightly higher mean scores than the females, there was no significant difference between the attitude of male and female teachers.

Some researchers believe that gender differences are strongly influenced by culture and contexts as well as the number of male and female respondents (Rieger, 2009; Islahi, 2019). Therefore, the previous studies related to gender differences were inconsistent and reached different and contradictory conclusions.

\subsection{The Present Study}

The main purpose of this study is to explore the Yemeni university students' attitudes towards using Google Classroom as a learning tool in a linguistic course at the University of Sana'a in Yemen during the academic year 2018/2019. This study is significant because it leads to a better understanding of how to enhance students' learning via computers and mobile phones in the Yemeni context. It also provides a clear picture of what the Yemeni students think about the use of computers and mobile phones in learning English.

\subsection{Research Questions}

This study attempts to address the following research questions:

1. What attitudes do Yemeni EFL university students have towards the use of Google Classroom as a learning tool?

2. Is there a statistically significant difference between the graduate and undergraduate students' attitudes towards using Google Classroom as a learning tool?

3. Is there a statistically significant difference between the male and female students' attitudes towards using Google Classroom as a learning tool?

\section{Method}

\subsection{Participants}

The participants of this study were one hundred and twenty fourth-year student teachers enrolled at the Bachelor in Education program and forty students enrolled at the Master in Education program at the University of Sana'a in Yemen. A total of 160 students participated in the study in the academic year 2018/2019. Out of the (160) participants of the study, 20 (12.5\%) were male students and $140(87.5 \%)$ were female students. Their ages ranged between 22 and 34 and all were speakers of the same first language (Arabic). Both the Bachelor program students and the Master program students have studied two linguistic courses each that involve the use of Google Classroom as a learning tool. They were taught by the same teacher (the researcher).

The undergraduate students were enrolled in a four-year program (a total of 152 Credit hours) leading to a bachelor's degree in teaching English as a Foreign Language (TEFL). Upon the completion of the requirements of the program, they would be granted a Bachelor of Education degree in the Teaching of English. Similarly, the graduate students were enrolled in a one-year program leading to a master's degree in teaching English as a Foreign Language (TEFL). Upon the completion of the requirements of the program which includes writing a thesis, they would be granted a Master of Education degree in the Teaching of English. 


\subsection{Instrument}

The instrument used to collect data for this study was a closed ended questionnaire that consisted of (40) items. The researcher constructed the items of the survey questionnaire depending on the relative research studies and relevant literature with specific reference to Pierceet al.(2007) and Ambu-Saidi (2010). Some other relevant research tools were used as sources of inspiration for the researcher to construct the instrument.

The participants were requested to respond to statements that aim to measure their own attitudes towards using Google Classroom as a learning tool, based on a five-point Likert scale ranging from (strongly agree, agree, undecided, disagree or strongly disagree). The scores for each item ranged from 1 to 5 .

The emergent copy of the questionnaire developed for the purpose of this study was out of forty items distributed on five domains as shown in Table (1) below.

Table (1): Distribution of Questionnaire Items on the Five Domains of the Scale, the Number of Items and Samples

\begin{tabular}{|c|c|c|}
\hline Domain & $\begin{array}{l}\text { Number of } \\
\text { items }\end{array}$ & Sample Item \\
\hline Technology Confidence (TC) & 10 & I feel comfortable using Google Classroom. \\
\hline $\begin{array}{l}\text { Attitude to Learning Linguistics } \\
\text { with Technology (AT) }\end{array}$ & 10 & $\begin{array}{l}\text { I like using computers/mobile phones in learning the } \\
\text { course. }\end{array}$ \\
\hline Linguistics Confidence (LC) & 5 & I am confident with linguistics courses. \\
\hline Behavioral Engagement (BE) & 9 & I try to answer questions the teacher asks. \\
\hline $\begin{array}{l}\begin{array}{l}\text { Developing } \\
\text { (LS) }\end{array} \\
\text { Language } \quad \text { Skills } \\
\end{array}$ & 6 & Google Classroom helps me improve my writing skill. \\
\hline
\end{tabular}

\subsection{Instrument Validity and Reliability}

For validity purposes, the researcher translated the English version of the instrument into Arabic. Then he translated the Arabic version back into English and made the necessary changes. After that, the final version of the questionnaire was given to some experts in education to check the construct validity of the research tool.

Taherdoost (2016) stated that in order for a test to be valid, it must be reliable. Reliability refers to the consistency across the parts of a measuring instrument. Therefore, in order to know that the data obtained for answering the research questions were interpretable, it was necessary to obtain a reliability score for the research tool of this study. The test reliability for the questionnaire was assessed using Cronbach's Alpha. The reliability of the research tool, containing (40) items was (0.95) which indicates high reliability.

\subsection{Data Analysis}


Following the collection of the questionnaires, the responses were computer-coded using the Statistical Package for Social Sciences (SPSS) Program. Data were first analyzed to yield descriptive statistics, including frequencies and percentages on the subjects' characteristics such as age and gender. The Independent Samples $t$ Test was computedto determine whether the student teachers' attitudes about using Google Classroom as a learning tool differ according to gender and level of study. The significance level in this study was set at $\mathrm{P}<0.05$. The criteria for interpreting the results are shown in Table (2) below.

Table (2): Criteria for Interpreting the Results

\begin{tabular}{l|l|l|l|l|l}
\hline $\begin{array}{l}\text { Degree } \\
\text { Agreement }\end{array}$ & of Strongly Agree & Agree & Neutral & Disagree & $\begin{array}{l}\text { Strongly } \\
\text { Disagree }\end{array}$ \\
\hline Mean & $5-4.20$ & $4.19-3.40$ & $3.39-2.60$ & $2.59-1.80$ & $1.79-1$ \\
\hline
\end{tabular}

\section{Results and Discussion}

The main focus of this study was to determine the attitudes of the Yemeni university students towards using mobile phones and computers technology in language learning. The examination of the data collected through survey questionnaires permitted a description of their attitudes towards using technology in English language learning. Table (3) below presents the mean and standard deviation of the five subscales of the students' attitudes towards technology.

Table (3): Mean and Standard Deviation Results for the Students' Sample on the Five Subscales

\begin{tabular}{l|l|l|l|l}
\hline Domain & $\mathrm{N}$ & Mean & Std. Deviation & $\begin{array}{l}\text { Degree of } \\
\text { Agreement }\end{array}$ \\
\hline Technology Confidence (TC) & 160 & 3.56 & 0.61 & Agree \\
\hline $\begin{array}{l}\text { Attitude to Learning Linguistics with } \\
\text { Technology (AT) }\end{array}$ & 160 & 3.76 & 0.62 & Agree \\
\hline Linguistics Confidence (LC) & 160 & 3.92 & 0.59 & Agree \\
\hline Behavioral Engagement (BE) & 160 & 4.09 & 0.55 & Agree \\
\hline Developing Language Skills (LS) & 160 & 4.04 & 0.75 & Agree \\
\hline Overall & 160 & 3.87 & 0.62 & Agree \\
\hline
\end{tabular}

Referring to Table (3) above, the responses of the participants to the questionnaire expressed as a mean score to the forty statements that were grouped into five domains. The Behavioral Engagement subscale came first with a mean of (4.09) out of (5), while the Technology Confidence subscale came last with a mean of (3.56). What follows is an analysis of the Yemeni students' perceptions about the attitudes associated with each subscale. 


\subsection{The Behavioural Engagement (BE)}

The Yemeni EFL student teachers were asked to respond to nine statements relating to their perceptions about the behavioral engagement. The statements, and the student teachers' responses, are shown in Table (4) below in a descending order.

Table (4): Descriptive Statistics and the Statements of the Behavioral Engagement

\begin{tabular}{|c|c|c|c|c|c|c|c|c|c|c|}
\hline \multirow[t]{2}{*}{$\overline{\mathrm{N}}$} & \multirow{2}{*}{$\begin{array}{l}\text { The Behavioral Engagement } \\
\text { Perception Scale }\end{array}$} & \multicolumn{2}{|c|}{ Disagree } & \multicolumn{2}{|c|}{ Neutral } & \multicolumn{2}{|c|}{ Agree } & \multirow[t]{2}{*}{ Mean } & \multirow[t]{2}{*}{ SD } & \multirow{2}{*}{$\begin{array}{l}\text { Degree of } \\
\text { Agreement }\end{array}$} \\
\hline & & $\mathrm{F}$ & $\%$ & $\mathrm{~F}$ & $\%$ & $\mathrm{~F}$ & $\%$ & & & \\
\hline 1 & $\begin{array}{l}\text { If I make mistakes, I work until I } \\
\text { have corrected them. }\end{array}$ & 2 & 1.2 & 2 & 1.2 & 156 & 97.6 & 4.52 & 0.59 & $\begin{array}{l}\text { Strongly } \\
\text { Agree }\end{array}$ \\
\hline 2 & $\begin{array}{l}\text { I try to answer questions the } \\
\text { teacher asks. }\end{array}$ & 1 & 0.6 & 4 & 2.5 & 155 & 96.9 & 4.45 & 0.58 & $\begin{array}{l}\text { Strongly } \\
\text { Agree }\end{array}$ \\
\hline 3 & $\begin{array}{l}\text { If I cannot do a task, I keep trying } \\
\text { different ideas. }\end{array}$ & 2 & 1.2 & 4 & 2.5 & 154 & 96.3 & 4.45 & 0.61 & $\begin{array}{l}\text { Strongly } \\
\text { Agree }\end{array}$ \\
\hline 4 & $\begin{array}{l}\text { I concentrate hard in linguistic } \\
\text { courses }\end{array}$ & 3 & 1.9 & 14 & 8.7 & 143 & 89.5 & 4.27 & 0.72 & $\begin{array}{l}\text { Strongly } \\
\text { Agree }\end{array}$ \\
\hline 5 & $\begin{array}{l}\text { I know how to use Google } \\
\text { Classroom effectively. }\end{array}$ & 12 & 7.5 & 17 & 10.6 & 131 & 81.9 & 4.06 & 0.87 & Agree \\
\hline 6 & $\begin{array}{l}\text { I like to read what my classmates } \\
\text { write on Google Classroom. }\end{array}$ & 14 & 8.7 & 21 & 13 & 125 & 78.3 & 4 & 0.93 & Agree \\
\hline 7 & $\begin{array}{l}\text { I get feedback on my } \\
\text { work/assignments on Google } \\
\text { Classroom. }\end{array}$ & 25 & 15.5 & 13 & 8.1 & 122 & 76.4 & 3.87 & 1.08 & Agree \\
\hline 8 & $\begin{array}{l}\text { I can contact my teacher at any } \\
\text { time when I need help on Google } \\
\text { Classroom. }\end{array}$ & 24 & 14.9 & 25 & 15.5 & 111 & 69.6 & 3.71 & 1.05 & Agree \\
\hline 9 & $\begin{array}{l}\text { I can master any computer } \\
\text { programs needed for the course. }\end{array}$ & 42 & 26.1 & 24 & 14.9 & 94 & 59 & 3.48 & 1.18 & Agree \\
\hline & Average & & & & & & & 4.09 & 0.55 & Agree \\
\hline
\end{tabular}

Table (4) shows that the average mean of the student teachers on the behavioral engagement perception scale was $4.09(81.8 \%)$. The results shown in the table above indicate that the means of the items associated with the behavioral engagement dimension ranged between (4.52) and (3.48). The highest rating was given to the statement: If I make mistakes, I work until I have corrected them, while the lowest rating was given to the statement: I can master any computer programs needed for the course. 


\subsection{Developing Language Skills (LS)}

The calculation of the means and standard deviations of the six statements relating to the student teachers' views and perceptions on Developing Language Skills (LS) were calculated. The statements, and the participants' responses, are shown in Table (5), below. They are reorganized to reflect how strongly the student teachers felt about each statement, in a descending order.

Table (5): Descriptive Statistics and the Statements of Developing Language Skills

\begin{tabular}{|c|c|c|c|c|c|c|c|c|c|c|}
\hline \multirow[t]{2}{*}{$\overline{\mathrm{N}}$} & \multirow[t]{2}{*}{ Developing Language Skills (LS) } & \multicolumn{2}{|c|}{ Disagree } & \multicolumn{2}{|c|}{ Neutral } & \multicolumn{2}{|c|}{ Agree } & \multirow[t]{2}{*}{ Mean } & \multirow[t]{2}{*}{ SD } & \multirow{2}{*}{$\begin{array}{l}\text { Degree of } \\
\text { Agreement }\end{array}$} \\
\hline & & $\mathrm{F}$ & $\%$ & $\mathrm{~F}$ & $\%$ & $\mathrm{~F}$ & $\%$ & & & \\
\hline 1 & $\begin{array}{l}\text { Google Classroom helps me } \\
\text { improve my writing skill }\end{array}$ & 7 & 4.3 & 5 & 3.1 & 148 & 92.6 & 4.36 & 0.82 & $\begin{array}{l}\text { Strongly } \\
\text { Agree }\end{array}$ \\
\hline 2 & $\begin{array}{l}\text { Google Classroom helps me } \\
\text { improve my grammar }\end{array}$ & 6 & 3.7 & 15 & 9.3 & 139 & 86.9 & 4.26 & 0.85 & $\begin{array}{l}\text { Strongly } \\
\text { Agree }\end{array}$ \\
\hline 3 & $\begin{array}{l}\text { Google Classroom helps me } \\
\text { improve my vocabulary }\end{array}$ & 8 & 5 & 14 & 8.7 & 138 & 86.3 & 4.22 & 0.85 & $\begin{array}{l}\text { Strongly } \\
\text { Agree }\end{array}$ \\
\hline 4 & $\begin{array}{l}\text { Google Classroom helps me } \\
\text { improve my reading skill }\end{array}$ & 12 & 7.5 & 11 & 6.8 & 137 & 85.7 & 4.14 & 0.91 & Agree \\
\hline 5 & $\begin{array}{l}\text { Google Classroom helps me } \\
\text { improve my English }\end{array}$ & 16 & 9.9 & 13 & 8.1 & 131 & 82 & 4.13 & 0.97 & Agree \\
\hline 6 & $\begin{array}{l}\text { Google Classroom helps me } \\
\text { improve my speaking skill }\end{array}$ & 53 & 32.9 & 47 & 29.2 & 60 & 37.9 & 3.14 & 1.15 & Neutral \\
\hline & Average & & & & & & & 4.04 & 0.75 & Agree \\
\hline
\end{tabular}

Given the results shown in Table (5) above, it can be stated that the students strongly agreed that Google Classroom helps them improve their writing skill( $\mathrm{M}=4.36)$, that Google Classroom helps them improve their grammar $(\mathrm{M}=4.26)$, and that Google Classroom helps them improve their vocabulary $(\mathrm{M}=4.22)$. They also agreed that Google Classroom helps them improve their reading skill ( $M=4.14)$ and that Google Classroom helps them improve their English in general $(M=4.13)$. They were also neutral about the last statement as shown in Table (5) above.

\subsection{Linguistics Confidence (LC)}

The calculation of the means and standard deviations of the five statements relating to the student teachers' views and perceptions on the Linguistics Confidence were calculated. The statements, and the participants' responses, are shown in Table (6), below. They are reorganized to reflect how strongly the student teachers felt about each statement, in a descending order. 
Table (6): Descriptive Statistics and the Statements of Linguistics Confidence

\begin{tabular}{|c|c|c|c|c|c|c|c|c|c|c|}
\hline \multirow[t]{2}{*}{$\bar{N}$} & \multirow{2}{*}{$\begin{array}{l}\text { Linguistics Confidence } \\
\text { Perception Scale }\end{array}$} & \multicolumn{2}{|c|}{ Disagree } & \multicolumn{2}{|c|}{ Neutral } & \multicolumn{2}{|c|}{ Agree } & \multirow[t]{2}{*}{ Mean } & \multirow[t]{2}{*}{ SD } & \multirow{2}{*}{$\begin{array}{l}\text { Degree of } \\
\text { Agreement }\end{array}$} \\
\hline & & $\mathrm{F}$ & $\%$ & $F$ & $\%$ & $\mathrm{~F}$ & $\%$ & & & \\
\hline 1 & $\begin{array}{l}\text { I can get good results in the } \\
\text { course. }\end{array}$ & 5 & 3.1 & 10 & 6.2 & 145 & 90.7 & 4.27 & 0.71 & $\begin{array}{l}\text { Strongly } \\
\text { Agree }\end{array}$ \\
\hline 2 & $\begin{array}{l}\text { I am confident with linguistic } \\
\text { courses. }\end{array}$ & 4 & 2.5 & 25 & 15.5 & 131 & 62 & 3.97 & 0.68 & Agree \\
\hline 3 & $\begin{array}{l}\text { In linguistic courses you get } \\
\text { rewards for your efforts. }\end{array}$ & 18 & 11.2 & 20 & 12.4 & 122 & 76.4 & 3.88 & 0.95 & Agree \\
\hline 4 & $\begin{array}{l}\text { I perform well in linguistic } \\
\text { courses. }\end{array}$ & 17 & 10.6 & 31 & 19.3 & 112 & 70.1 & 3.79 & 0.88 & Agree \\
\hline 5 & $\begin{array}{l}\text { I know I can handle difficulties in } \\
\text { linguistic courses. }\end{array}$ & 20 & 12.4 & 39 & 24.2 & 101 & 63.4 & 3.68 & 0.92 & Agree \\
\hline & Average & & & & & & & 3.92 & 0.59 & Agree \\
\hline
\end{tabular}

Table (6) above shows that the average mean of the student teachers on the Linguistics Confidence (LC) scale was 3.92 (78.4\%). The results shown in the table above indicate that the means for the five statements regarding the Linguistics Confidence ranged between (4.27) and (3.68). As for the total average of the five statements, the mean was 3.92. The highest rating was given to the statement: I can get good results in the coursewith a mean of (4.27), followed by the statement: I am confident with linguistic courses with a mean of (3.97). Then came the statement: In linguistic courses you get rewards for your efforts with a mean of (3.88), followed by the statement: I perform well in linguistic courseswith a mean of (3.79). In the last rank came the statement: I know I can handle difficulties in linguistic courses with a mean of (3.68).

\subsection{Attitude to Learning Linguistics with Technology (AT)}

The calculation of the means and standard deviationsof the ten statements relating to the student teachers' views and perceptions on theAttitude to Learning Linguistics with Technology (AT) were calculated. The statements, and the participants' responses, are shown in Table (7), below. They are reorganized to reflect how strongly the student teachers felt about each statement, in a descending order.

Table (7): Descriptive Statistics and the Statements of the Attitude to Learning Linguistics with Technology (AT)

\begin{tabular}{|c|c|c|c|c|c|c|c|c|c|}
\hline \multirow[t]{2}{*}{$\overline{\mathrm{N}}$} & \multicolumn{2}{|c|}{ Attitude to Learning Linguistics Disagree } & \multicolumn{2}{|c|}{ Neutral } & \multicolumn{2}{|c|}{ Agree } & \multirow[t]{2}{*}{ Mean } & \multirow[t]{2}{*}{ SD } & \multirow{2}{*}{$\begin{array}{l}\text { Degree of } \\
\text { Agreement }\end{array}$} \\
\hline & with Technology (AT) & $\%$ & $\mathrm{~F}$ & $\%$ & $\mathrm{~F}$ & $\%$ & & & \\
\hline 1 & $\begin{array}{l}\text { Google Classroom enables me to } 4 \\
\text { go back and check what I have }\end{array}$ & 2.5 & 6 & 3.7 & 150 & 93.8 & 4.43 & 0.69 & $\begin{array}{l}\text { Strongly } \\
\text { Agree }\end{array}$ \\
\hline
\end{tabular}




\begin{tabular}{|c|c|c|c|c|c|c|c|c|c|c|}
\hline & read. & & & & & & & & & \\
\hline 2 & Google Classroom is useful. & 12 & 7.5 & 7 & 4.3 & 141 & 88.2 & 4.15 & 0.90 & Agree \\
\hline 3 & Google Classroom is easy to use & 16 & 9.9 & 10 & 6.2 & 134 & 83.8 & 4.05 & 0.94 & Agree \\
\hline$\overline{4}$ & $\begin{array}{l}\text { I get a sense of satisfaction when } \\
\text { I do activities on Google } \\
\text { Classroom. }\end{array}$ & 16 & 9.9 & 12 & 7.5 & 132 & 82.8 & 4.03 & 0.94 & Agree \\
\hline 5 & $\begin{array}{l}\text { The use of Google Classroom } \\
\text { motivates me. }\end{array}$ & 15 & 9.3 & 21 & 13 & 124 & 77.7 & 3.92 & 0.90 & Agree \\
\hline 6 & $\begin{array}{l}\text { Learning the course using } \\
\text { Google Classroom is enjoyable. }\end{array}$ & 24 & 14.9 & 17 & 10.6 & 119 & 74.5 & 3.85 & 1.06 & Agree \\
\hline$\overline{7}$ & $\begin{array}{l}\text { Google Classroom and } \\
\text { computers help me learn the } \\
\text { course better. }\end{array}$ & 21 & 13 & 15 & 9.3 & 124 & 77.7 & 3.83 & 0.92 & Agree \\
\hline 8 & $\begin{array}{l}\text { I like using computers in } \\
\text { learning the course. }\end{array}$ & 29 & 18 & 26 & 16.1 & 105 & 65.9 & 3.66 & 1.07 & Agree \\
\hline 9 & $\begin{array}{l}\text { The course is more interesting } \\
\text { when using computers. }\end{array}$ & 32 & 19.9 & 20 & 12.4 & 108 & 67.7 & 3.61 & 1.11 & Agree \\
\hline 10 & $\begin{array}{l}\text { The use of Google Classroom is } \\
\text { a waste of time. }\end{array}$ & 119 & 73.9 & 16 & 10.6 & 25 & 15.6 & 2.09 & 1.07 & Disagree \\
\hline & Average & & & & & & & 3.76 & 0.62 & Agree \\
\hline
\end{tabular}

Table (7) shows that the average mean of the student teachers on the Attitude to Learning Linguistics with Technology (AT) scale was 3.76 (75.2\%). The results shown in the table above indicate that the students strongly agreed that Google Classroom enables them to go back and check what they have read $(M=4.43)$. They agreed that they like using computers in learning the course $(M=3.66)$, and that learning the course using Google Classroom is enjoyable $(M=3.85)$. Similarly, they agreed that Google Classroom and computers help them learn the course better $(\mathrm{M}=3.83)$, that they get a sense of satisfaction when they do activities on Google Classroom $(M=4.03)$, and that the course is more interesting when using computers $(M=3.61)$. They also agreed that Google Classroom is easy to use $(M=4.05)$, but they disagreed about the statement which states that the use of Google Classroom is a waste of time $(\mathrm{M}=2.09)$.

\subsection{Technology Confidence (TC)}

The calculation of the means and standard deviations of the ten statements relating to the students' views and perceptions on the technology confidence were calculated. The statementsand the participants' responses are shown in Table (8), below. They are reorganized to reflect how strongly the student teachers felt about each statement in a descending order. 
Table (8): Descriptive Statistics and the Statements of the Technology Confidence

\begin{tabular}{|c|c|c|c|c|c|c|c|c|c|c|}
\hline \multirow[t]{2}{*}{$\overline{\mathrm{N}}$} & \multirow{2}{*}{$\begin{array}{l}\text { Technology Confidence } \\
\text { Perception Scale }\end{array}$} & \multicolumn{2}{|c|}{ Disagree } & \multicolumn{2}{|c|}{ Neutral } & \multicolumn{2}{|c|}{ Agree } & \multirow{2}{*}{\multicolumn{2}{|c|}{ Mean SD }} & \multirow{2}{*}{$\begin{array}{l}\text { Degree o } \\
\text { Agreement }\end{array}$} \\
\hline & & $\bar{F}$ & $\%$ & $\mathrm{~F}$ & $\%$ & $\mathrm{~F}$ & $\%$ & & & \\
\hline 1 & $\begin{array}{l}\text { I learned to use Google } \\
\text { Classroom quickly. }\end{array}$ & 14 & 8.7 & 7 & 4.3 & 139 & 86.9 & 4.21 & 0.90 & $\begin{array}{l}\text { Strongly } \\
\text { Agree }\end{array}$ \\
\hline 2 & $\begin{array}{l}\text { I can use Google Classroom } \\
\text { successfully every time }\end{array}$ & 23 & 14.3 & 8 & 5 & 129 & 80.8 & 4.02 & 0.99 & Agree \\
\hline$\overline{3}$ & $\begin{array}{l}\text { I am satisfied with Google } \\
\text { Classroom }\end{array}$ & 20 & 12.4 & 11 & 6.8 & 129 & 80.8 & 3.96 & 0.98 & Agree \\
\hline$\overline{4}$ & $\begin{array}{l}\text { I am a high-level user of Google } \\
\text { Classroom. }\end{array}$ & 18 & 11.2 & 20 & 12.4 & 122 & 76.4 & 3.88 & 0.91 & Agree \\
\hline 5 & $\begin{array}{l}\text { I feel comfortable using Google } \\
\text { Classroom. }\end{array}$ & 17 & 10.6 & 20 & 12.4 & 124 & 77 & 3.84 & 0.93 & Agree \\
\hline 6 & $\begin{array}{l}\text { Google Classroom meets my } \\
\text { needs. }\end{array}$ & 20 & 12.4 & 22 & 13.7 & 118 & 73.9 & 3.81 & 0.96 & Agree \\
\hline 7 & I am good at using computers. & 34 & 21.1 & 22 & 13.7 & 105 & 65.2 & 3.64 & 1.13 & Agree \\
\hline 8 & $\begin{array}{l}\text { It is easier for me to use Google } \\
\text { Classroom to write my } \\
\text { assignments than using paper and } \\
\text { pen. }\end{array}$ & 47 & 29.2 & 23 & 14.3 & 90 & 56.5 & 3.48 & 1.35 & Agree \\
\hline 9 & $\begin{array}{l}\text { I can fix a lot of computer } \\
\text { problems }\end{array}$ & 81 & 50.3 & 35 & 21.7 & 44 & 28 & 2.74 & 1.16 & Neutral \\
\hline$\overline{10}$ & $\begin{array}{l}\text { I am not good at using Google } \\
\text { Classroom. }\end{array}$ & 134 & 83.9 & 9 & 5.6 & 17 & 10.5 & 1.98 & 0.98 & Disagree \\
\hline & Average & & & & & & & 3.56 & 0.61 & Agree \\
\hline
\end{tabular}

Table (8) above shows that the average mean of the students on the technology confidence perception scale was $3.56(71.2 \%)$. The results shown in the table indicate that the students strongly agreed that they learned to use Google Classroom quickly $(\mathrm{M}=4.21)$. They agreed that they can use Google Classroom successfully every time $(M=4.02)$, and that they were satisfied with Google Classroom $(M=3.96)$. Similarly, they agreed that they were high-level users of Google Classroom ( $\mathrm{M}=3.88)$, that they feel comfortable using Google Classroom $(\mathrm{M}=3.84)$, and that Google Classroom meets their needs $(\mathrm{M}=3.81)$. They also agreed that they were good at using computers $(M=3.64)$, and that it was easier for them to use Google Classroom to write their assignments than using paper and pen $(M=3.48)$. They were neutral about the statement which states that they can fix a lot of computer problems $(M=2.74)$, but they disagreed that they were not good at using Google Classroom ( $\mathrm{M}=0.98)$. 


\subsection{Academic Level Differences}

The aim of the second research question of this study was to determine whether the student teachers' attitudes towards using mobile phones and computers as a learning tool differ according to the academic level of the students. To answer this question, the Independent Samples t Test was computed as shown in Table (9) below:

Table (9): Independent Samples t Test

\begin{tabular}{lllllll}
\hline & Level & $\mathrm{N}$ & Mean & $\begin{array}{l}\text { Std. } \\
\text { Deviation }\end{array}$ & $\mathrm{t}$ & $\begin{array}{l}\text { Sig. } \\
\text { tailed })\end{array}$ \\
\hline TC & Undergraduate & 120 & 3.51 & 0.63 & -1.757 & 0.081 \\
\hline & Graduate & 40 & 3.70 & 0.50 & & \\
\hline AT & Undergraduate & 120 & 3.70 & 0.64 & -2.193 & 0.030 \\
\hline & Graduate & 40 & 3.95 & 0.49 & & \\
\hline LC & Undergraduate & 120 & 3.82 & 0.56 & -3.920 & 0.000 \\
\hline & Graduate & 40 & 4.23 & 0.61 & & \\
\hline BE & Undergraduate & 120 & 4.02 & 0.55 & -2.706 & 0.008 \\
\hline & Graduate & 40 & 4.29 & 0.49 & & \\
\hline LS & Undergraduate & 120 & 4.08 & 0.72 & 0.975 & 0.331 \\
\hline & Graduate & 40 & 3.94 & 0.85 & & \\
\hline Overall & Undergraduate & 120 & 3.83 & 0.54 & -2.080 & 0.039 \\
\hline & Graduate & 40 & 4.02 & 0.47 & & \\
\hline & & & & & & \\
\hline
\end{tabular}

Table (9) above shows that the average mean of the undergraduate students on their attitudes towards using mobile phones and computers as a learning tool was 3.83 while the average mean of their graduate counterparts was 4.02. The mean scores of the undergraduate students and the graduate students were compared using a T- test. This analysis resulted in a $\mathrm{T}$ - score of $(-2.08)(\mathrm{P}<$ 0.039). This means that the difference between the two samples was statistically significant at $\mathrm{P}<$ 0.05. The results clearly demonstrate that the graduate students' attitudes towards using computers and mobile phones as a learning tool were higher than that of the undergraduate students. In other words, the higher the level of study the more positive attitude will be.

\subsection{Gender Differences}

The aim of the third research question of this study was to determine whether the students' attitudes towards using mobile phones and computers as a learning tool differ according to gender. To answer this question, the Independent Samples t Test was computed as shown in Table (10) below: 
Table (10): Independent Samples t Test

\begin{tabular}{lllllll}
\hline & Gender & $\mathrm{N}$ & Mean & $\begin{array}{l}\text { Std. } \\
\text { Deviation }\end{array}$ & $\mathrm{t}$ & $\begin{array}{l}\text { Sig. (2- } \\
\text { tailed) }\end{array}$ \\
\hline TC & Male & 20 & 3.69 & 0.68 & 1.045 & 0.298 \\
\hline & Female & 140 & 3.54 & 0.59 & & \\
\hline AT & Male & 20 & 3.88 & 0.57 & .876 & 0.383 \\
\hline & Female & 140 & 3.75 & 0.62 & & \\
\hline LC & Male & 20 & 4.29 & 0.53 & 3.057 & 0.003 \\
\hline BE & Female & 140 & 3.87 & 0.59 & & \\
\hline & Male & 20 & 4.35 & 0.41 & 2.302 & 0.023 \\
\hline LS & Female & 140 & 4.05 & 0.56 & & \\
\hline & Male & 20 & 3.76 & 0.79 & -1.814 & 0.072 \\
\hline Overall & Male & 20 & 3.99 & 0.49 & 1.114 & 0.267 \\
& Female & 140 & 3.86 & 0.54 & & \\
\hline
\end{tabular}

Table (10) shows that the average mean of the male students on their attitudes towards using Google Classroom as a learning tool was 3.99 while the average mean of their female counterparts was 3.86. The mean scores of the male students and the females were compared using a $\mathrm{T}$ - test. This analysis resulted in a $\mathrm{T}$ - score of $(1.114)(\mathrm{P}<0.267)$. This means that the difference between the two samples was not statistically significant at $\mathrm{P}<0.05$. The results clearly demonstrate that the male students' attitudes towards using Google Classroom as a learning tool were the same as that of the female students. This result lends support to the findings of Abedalaziz, Jamaluddin and Leng (2013); Awad and Alkaraki (2013), Kitchakarn (2015), and Islahi (2019) who found no differences in the attitudes of male and female students towards using computers as a learning tool.

\section{Conclusion}

The current study has explored the Yemeni EFL university students towards the use of computers and mobile phones as a learning tool. The results of this study indicated that the students' attitudes towards using computers and phones as a learning tool were favorably positive. There was a statistically significant difference between the attitudes of the undergraduate and graduate students towards using computers and mobile phones as a learning tool in favor of the graduate students. However, there was no statistically significant difference between male and female students in terms of their attitudes towards using computers and mobile phones.

The findings of this study suggest some pedagogical implications and some future research directions. It would be a good idea if the higher institutions authorities develop the teachers' 
competency in the use of technology in their classrooms in order to successfully integrate the free tools such as Google Classroom into their classes. The teachers should help their students by including some links of reliable resources that the students can use to develop their language skills. Furthermore, the teachers should also train their students in searching for and integrating information to support their assignments. They should also get into the habit of commenting on the students' assignments on Google Classroom because the students like this practice and that will help them to revise their assignments.

Concerning the future research directions, it would be a good idea to survey a larger sample of students and to expand the scope of the study to other private universities in Yemen. Furthermore, future studies should compare these with the attitudes of students taking traditional English language classes. Future research studies should examine the relationship between the students' attitudes towards using technology as a learning tool and their academic achievement.

\section{References}

[1] Abedalaziz, N., Jamaluddin, S. \& Leng, C.H. (2013). Measuring attitudes towards computer and internet usage among postgraduate students in Malaysia. The Turkish Online Journal of Educational Technology,12(2), 200-216.http://www.tojet.net/articles/v12i2/12219.pdf

[2] Almekhlafi, A. (2006). The effect of computer assisted language learning (CALL) on United Arab Emirates English as a foreign language (EFL) school students' achievement and attitude. Journal of Interactive Research,17(2), 121142.https://www.learntechlib.org/p/64230/

[3] Ambu-Saidi, S. (2010). Student and Teacher Attitudes towards the Use of Language Learning Technology (LLT) in a Tertiary English Course in Oman. [Unpublished MA thesis]. The University of Queensland.

[4] Awad, A. \& Alkaraki, S. (2013). Attitudes of EFL students towards using computers in learning English. English for Specific Purposes World,13(37), 1-20.

[5] Behroozian, R. \& Sadeghoghli, H. (2017). A study of students' attitudes toward using technology in second language learning. Journal of Applied Linguistics and Language Research,4(8), 201-216.

[6] Colley, A., and Comber, C. (2003). Age and gender differences in computer use and attitudes among secondary school students: What has changed? Educational Research,45(2), 155165.

[7] Google classroom. (2019, August 16). In Wikipedia. https://en.wikipedia.org/wiki/Google Classroom

[8] Islahi, F. (2019). Exploring teacher attitude towards information technology with a gender perspective. Contemporary Educational Technology, 10(1), 37-54.

[9] Karakaya, Kadir. (2010). An investigation of English language teachers' attitudes toward computer technology and their use of technology in language teaching. [Unpublished MA thesis]. Middle East Technical University. 
[10] Kitchakarn, O. (2015). EFL learners' attitudes towards using computers as a learning tool in language learning. The Turkish Online Journal of Educational Technology, 14(2). 52-58.

[11] Nicholas, B. J., Rossiter, M. J., and Abbott, M. L. (2011). The power of story in the ESL classroom. The Canadian Modern Language Review, 67(2), 247-268.

[12] Pierce, R., Stacey, R., \& Barkatsas, A. (2007). A new scale for monitoring students' attitudes to learning mathematics with technology (MTAS). Computer \& Education, 48(2), 285-300. https://doi.org/10.1016/j.compedu.2005.01.006

[13] Rieger, B. (2009). Hungarian university students' beliefs about language learning: A questionnaire study. WoPaLP,3, 97-113. http://langped.elte.hu/WoPaLP3-2009.htm

[14] Sainz, M., and Saez, M. L. (2010). Gender differences in computer attitude and the choice of technology related occupations in a sample of secondary students in Spain. Computers \& Education,54(2), 578-587.

[15] Sánchez, J. J. C., \&Alemán, E. C. (2011). Teachers' opinion survey on the use of ICT tools to support attendance-based teaching. Computers and Education,56(3), 911-915. https://doi.org/10.1016/j.compedu.2010.11.005

[16] Savvidis, P. (2016). Top 6 benefits of using technology in the classroom.Webanywhere. https://www.webanywhere.co.uk/.Retrieved June 3, 2019, from https://www.webanywhere.co.uk/blog/2016/02/top-6-benefits-technology-classroom/

[17] Sreedhar, S. \& Amos, J. (2016). An assessment of ICT integration in English language learning: A

[18] glimpse of student's perspective in HEI. ELT Voices- International Journal for Teachers of English,6(1), 17-30.

[19] Taherdoost, H. (2016). Validity and reliability of the research instrument; how to test the validation of a questionnaire/survey in a research. International Journal of Academic Research in Management (IJARM),5(3), 28-36.

[20] Teo, T., Fan, X. \& Du, J. (2015). Technology acceptance among pre-service teachers: Does gender matter? Australasian Journal of Educational Technology,31(3), 235-251.

[21] Tomar, A. (2016). Use of technology in language learning. ELT Voices- International Journal for Teachers of English,6(2), 9-15.

[22] Tondeur, J., Cooper, M., \& Newhouse, C. P. (2010). From ICT coordination to ICT integration: A longitudinal case study. Journal of Computer Assisted Learning,26(4), 296306.

[23] Venkatesh, V., \&Bala, H. (2008). Technology acceptance model 3 and a research agenda on interventions. Decision Sciences, 39,273-315.

[24] Yang, S. (2017). A study of students' attitudes towards using ICT in a social constructivist environment. Australasian Journal of Educational Technology,33(5), 50-62. 